\title{
CFD を用いた高亜音速域におけるウィングロック現象の解析*1 Analyses of High-Subsonic Wing Rock Phenomena by CFD
}

\author{
滝 田雄 一*2. 宮 路 幸 二*3 \\ Yuichi TAKITA and Koji MrYAJI
}

Key Words : Delta Wing, CFD, PSP, Unsteady Aerodynamics

\begin{abstract}
A wing rock is known to be a self-excited rolling oscillation of a delta wing that is induced by unsteady aerodynamic forces. In previous studies, we carried out coupled simulations of a flow simulation (CFD) and an equation of motion of a delta wing to reproduce and understand a wing-rock motion observed by low-subsonic wind-tunnel experiments. The objective of the present study is to simulate high-subsonic wing rock phenomena and compare simulations with the visualized flow data by the latest experiments. A numerical model of a friction torque around the rolling axis in the experiment is introduced to search the reason for the discrepancies between the experiments and the simulations. Unsteady pressure changes on the wing obtained by the pressure sensitive paint (PSP) technique show reasonable agreements.
\end{abstract}

\section{1. は じめに}

デルタ翼は，遷音速や超音速における造波抵抗の低さか ら超音速航空機や宇宙往還機などに用いられる。しかし，揚 力傾斜が小さいために離着陸時に大迎角をとらなければな らず，このような状況下でロール軸周りの自励振動を起こ し得ることが知られている。この機体の振動はデル夕翼の 前縁剥離渦の変動によって引き起こされ, ウィングロック と呼ばれる。 ウィングロックの発生を予測し, そのメカニ ズムを明らかにすることは今後の高速航空機の安全な航行 を考える上で重要である.

過去に風洞実験と数值計算の両面からウィングロックに関 する多くの研究が行われきた. 著者らは, 気流速度 $20[\mathrm{~m} / \mathrm{s}]$ の低速風洞におけるデルタ翼ウイングロック1)を再現する 数值シミュレーションに関する研究を行った ${ }^{21}$. CFD と翼 の運動方程式を連成させて解き, 特徽的な翼の運動と無次 元振動数について実験と良好な一致を得たが，気流マッハ 数を厳密に一致させることが困難であったため, ロール角 振幅の予測精度に問題を残した。 著者らの報告を含め, 過 去のウィングロックの研究の多くは気流マッハ数 0.2 程度 以下の低速域に限られており ${ }^{3,4}$, 高亚音速域におけるもの はほとんど見られない.しかし, 先に述べたデルタ翼の揚 力特性から, 翼後退角の小さな亜音速機よりも高速・大迎 角での離着陸が要求されること, また, 近年開発が進めら れている再使用可能な宇宙往還機では, 高高度から大迎角 をとりながらの減速が必要とされるため, ウィングロック が発生しやすい条件下の飛行となる。近年，浅井らによっ て行われた高亜音速域におけるロール自由のウィングロッ

\footnotetext{
*1 C) 2009 日本航空宇宙学会

平成 20 年 9 月 18 日原稿受理

*2 横浜国立大学大学院工学府システム統合工学専攻

*3 横浜国立大学大学院工学研究院システムの創生部門
}

クの風洞実験5,6) は，このような背景に応えるものとして 注目される。マッハ数と迎角を変化させて実験が行われ, 特にマッハ数 0.5 , 迎角 $35^{\circ}$ の条件で詳細な計測が行われ た. 同実験は高速非定常運動する際の翼面上圧力を感圧塗 料 (PSP) により取得することも目的としている．従来の ウィングロックの実験では，翼のロール角のみを取得した ものが大半であったが，得られた圧力の面データと CFD 解析を組み合わせることで飛躍的に多くの情報量が得られ， 相互検証と現象の理解に役立つ.

本研究は，実験と CFD の融合によりウィングロックの メカニズムを詳細に調査し, 自由飛行試験によらないデル 夕翼機の動安定性解析を可能にするための研究の一部と位 置付けられる。特に本論文では, ベアリング摩擦の影響な ど，風洞実験と自由飛行試験の差を明確に示すこと，また， 感圧塗料を用いた非定常圧力分布計測と CFD の結果を比 較することで, 空気力・モーメントだけでなく局所的な流 れの様子を調べ，更に，最新の計測法と CFD 双方の精度 と問題点を調べることを目的とする.

\section{2. 数 值 計 算 法}

流体と翼の運動を同時に解くために, CFD と翼運動方 程式の連成解法を用いる. 文献 2) と同様の手法であり, 以 下に概要を述べる。流体計算は薄層近似 Navier-Stokes 方 程式を有限差分法により解く. 対流項の離散化には Roeの Flux Difference Splitting MUSCL 法により高次精度化 した風上差分法を用い，粘性項には 2 次精度中心差分を用 いる. 時間積分には次式の 3 点後退差分を LU-ADI 法7) と Newton 反復法により 2 次精度化した陰解法を用いる。

$$
\frac{3}{2 \Delta t} Q^{n+1}-\frac{2}{\Delta t} Q^{n}+\frac{1}{2 \Delta t} Q^{n-1}=R\left(Q^{n+1}\right)
$$


ここで $Q$ は流体の保存変数, $R$ は非粘性項, 粘性項から なる Navier-Stokes 方程式の定常項である。

流体計算に打ける格子の移動は次式の壁面境界条件,

$$
u=x_{\tau}, \quad v=y_{\tau}, \quad w=z_{\tau}
$$

及びメトリックスの時間項,

$$
\begin{aligned}
\xi_{t} & =-\left(\xi_{x} x_{\tau}+\xi_{y} y_{\tau}+\xi_{z} z_{\tau}\right) \\
\eta_{t} & =-\left(\eta_{x} x_{\tau}+\eta_{y} y_{\tau}+\eta_{z} z_{\tau}\right) \\
\zeta_{t} & =-\left(\zeta_{x} x_{\tau}+\zeta_{y} y_{\tau}+\zeta_{z} z_{\tau}\right)
\end{aligned}
$$

を考慮することにより反映される。ここで $\left(x_{\tau}, y_{\tau}, z_{\tau}\right)$ は 計算格子点の移動速度である。

ロール軸周りに回転する翼（剛体）の運動方程式は,

$$
I_{x} \frac{\mathrm{d}^{2} \phi}{\mathrm{d} t^{2}}+f\left(\frac{\mathrm{d} \phi}{\mathrm{d} t}\right)=M_{r}
$$

で表される．ただし， $I_{x}$ はロール軸周りの翼の慣性モーメ ント, $\phi$ はロール角, $M_{r}$ は空気力から求められるローリ ングモーメントである. また, 左辺第 2 項 $f(\dot{\phi})$ は実験に 扔ける回転軸のベアリングの摩擦を模擬する項であり，後 述するように今回の解析では大きな影響を持つ. 式 (4)を 2 段 2 次精度の Runge-Kutta 法を用いて解く. 従って運動 方程式の 1 時間ステップ当たり流体計算を 2 回行い, その 1 回ごとに上記の内部反復を行う. 反復回数は 3 回とした. 式 (4) より得られる新たな格子点座標と格子点移動速度を 式 (2), (3) に反映して, 再び式 (1) を解く.

\section{3. 計算対象および条件}

デルタ翼の前縁後退角は $80^{\circ}$, 翼弦長に対する翼厚は $0.027 \%$, 前縁はシャープエッジで, 翼弦に垂直な断面形 状は台形である。ロール軸周りの慣性モーメントは $I_{x}=$ $39.63[\mathrm{~g} \cdot \mathrm{cm}]$ である。第 1 図に実験 5,6$)$ で用いられたデル 夕翼模型と CFD に用いた計算格子を示す。翼幅中央部の スティングによるふくらみが翼面上の渦の移動に影響を及 ぼすため，スティングを含めた計算格子を生成した．格子 点数は, 翼弦方向に 75 点, 円周方向に 191 点, 翼面から 離れる方向に 71 点の計 $1,017,075$ 点である.

気流条件は, 非定常 PSP 計測が行われたマッハ数 $M=$ 0.5 , ロール軸に対する気流迎角 $\alpha=35^{\circ}$ ，レイノルズ数は 翼弦長基準で $R e=2.30 \times 10^{6}$ とする. 同条件は, 高亜音
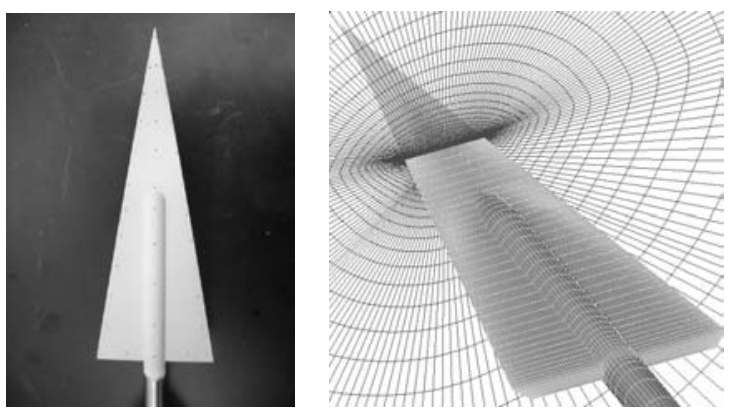

第 1 図 実験模型と計算格子
速域でのいくつかのマッ八数と迎角の中で, 大振幅で最も 明確な周期性を示すものとして報告されている。また，同 条件を含み, マッ八数固定で迎角を $25 \sim 40^{\circ}$ まで $5^{\circ}$ 間隔 で変化させて, ウィングロックの発生範囲を調べるための 解析も行った.

\section{4. 結果および考察}

4.1 ロール軸周りリミットサイクル振動 マッハ数 $M=$ 0.5 , 迎角 $\alpha=35^{\circ}$ の結果を示す. 同条件でロール角 $0^{\circ}$ 固 定の定常解を求め, これを初期解としてロール自由の計算 を行った。はじめに文献 2) と同じく, 実験のベアリング摩 擦のない計算, すなわち式 (4)の第 2 項で $f(\dot{\phi})=0$ とした 計算を行った，第 2 図は，静止状態からのロール角の時間 履歴を計算と実験で比較したものである。ロール角の振幅 が徐々に増加し, 動的に中立安定なりミットサイクルに至 る過程が得られた。 しかし, 計算で得られた振幅が約 $40^{\circ}$ であるのに対し, 実験の振幅は半分の $20^{\circ}$ である.また, 振動周波数 $f[\mathrm{~Hz}]$ を最大翼幅 $b[\mathrm{~m}]$ と一様流速度 $U[\mathrm{~m} / \mathrm{s}]$ で無次元化した振動数 $\Omega=\pi b f / U$ に関しては, 計算結果 $\Omega=0.068$, 実験結果 $\Omega=0.075$ となった.

これら不一致の原因として, 模型支持（スティング）に かかる摩擦が考えられる。第 3 図に風洞実験で用いられた デルタ翼の模型とスティング内部の図を示す。スティング を支えるべアリングの摩擦に注意する必要がある. 文献 1) においては，ベアリングのオイルを交換するなどして，摩 擦卜ルクを $0.5 \times 10^{-3}[\mathrm{~N} \cdot \mathrm{cm}]$ 程度に減じる処置がなされ たが，今回の実験では特別な処置はなされていない.

そこで, 式 (4) に示した摩擦トルクを考慮したモデルを 導入して同じ気流条件の計算を行った。摩擦トルクは簡単 に, 次式の角速度の線形モデルで表されると仮定する。

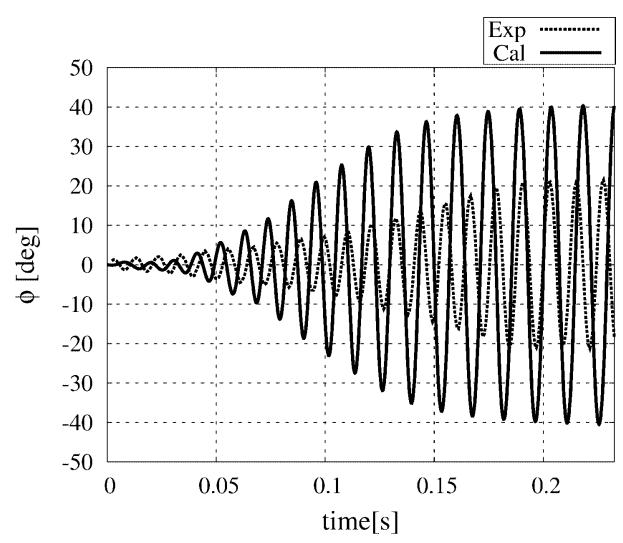

第 2 図 ロール角の時間履歴

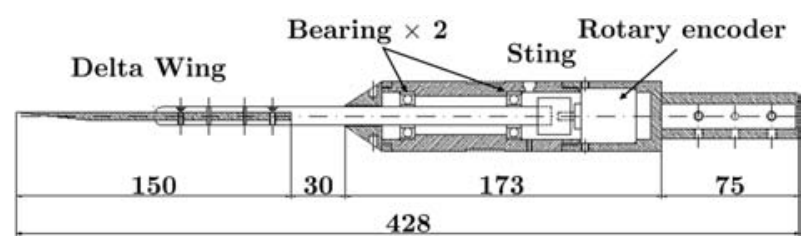

第3図＼cjkstart風洞実験で用いられた実験装置5,6) 


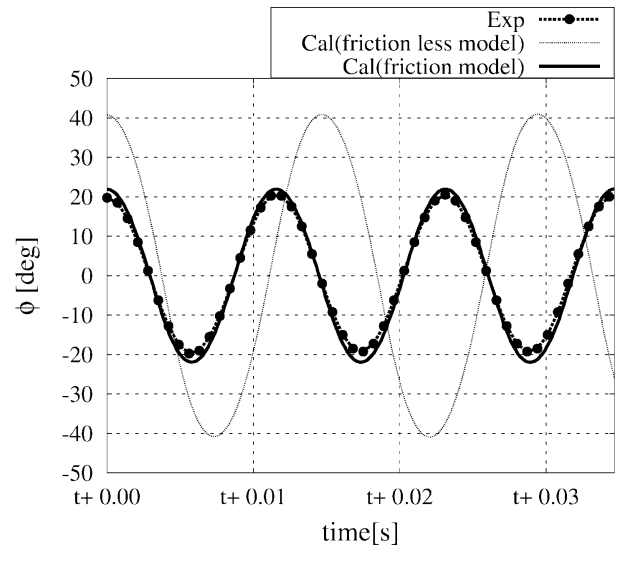

第 4 図 リミットサイクル時におけるロール角の時間履歴

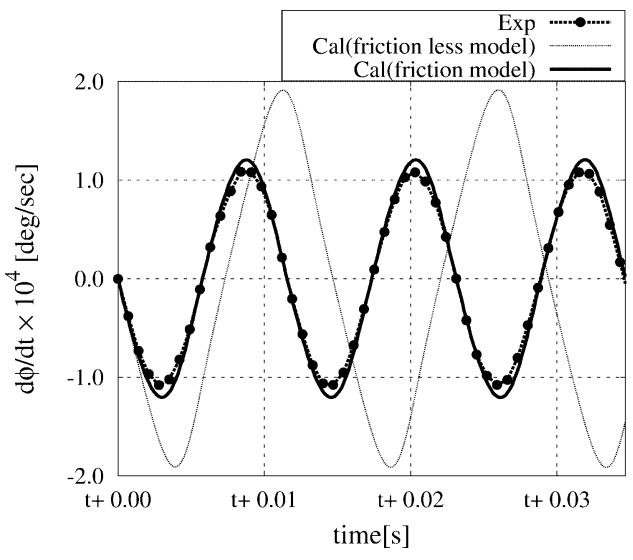

第 5 図 リミットサイクル時におけるロール角速度の時間履歴

$$
f(\dot{\phi})=c \dot{\phi}
$$

係数 $c$ を決定するために, 計算と実験のロール角加速度よ りモーメントの差を見積もり，ロール角速度の大きさを式 (5)に代入して $c$ のお抢よその值を決めた。 その後実際に 連成計算でロール角振幅がほぼ一致するよう值を決定した。 その結果, 摩擦係数は $c=0.13 \times 10^{-3}[\mathrm{~N} \cdot \mathrm{m} \cdot \mathrm{s}]$ となった. また，摩擦なしの非定常解を初期解とするとウィングロッ ク運動が変化する恐れがあるため, ロール 0 固定の定常解 から摩擦を加えた自由振動の計算を行った。

リミットサイクルに至った後のロール角, ロール角速度, ロール角加速度の約 3 周期分の時間履歴を，それぞれ第 4 ～ 6 図に示す。実験結果を破線十丸印で, 摩擦モデルの計算結 果を実線で，摩擦を加えない結果を点線で示す、ロール角 の振幅を調整するよう摩擦係数 $c$ を決定した結果, 振動周 期が一致し, 更に角速度と角加速度の振幅についても定量 的な一致を得た。これらより，用いた摩擦モデルが実際の 現象を適切に模擬していると言える。

摩擦の有無により翼の運動に生じる違いについて考察す る. 第 4 図のロール角 $\phi$ の履歴はいずれも正弦関数に類似 しているが，時間微分するに従って定性的な違いが現れる。 特に, 第 6 図のロール角加速度 $\ddot{\phi}$, すなわちローリングモー メントに拀いてその差が顕著である。摩擦のない場合, 角 加速度が鋭いピークから急減し, 変化率が緩やかになって

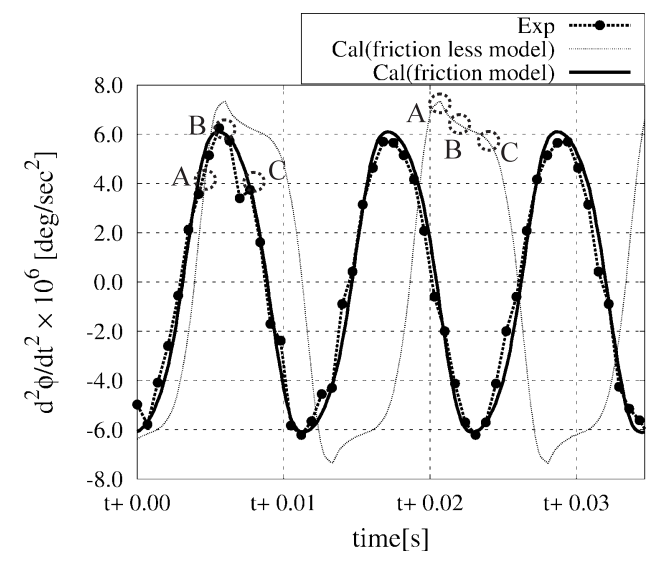

第 6 図 リミットサイクル時におけるロール角加速度の時間履歴

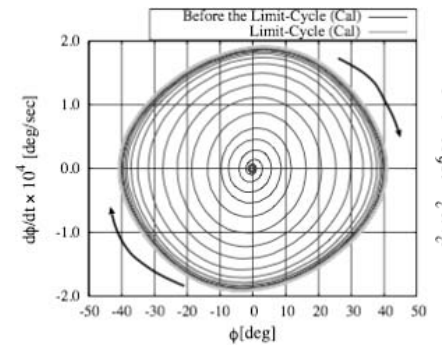

(a) $\phi-\dot{\phi}$ 平面

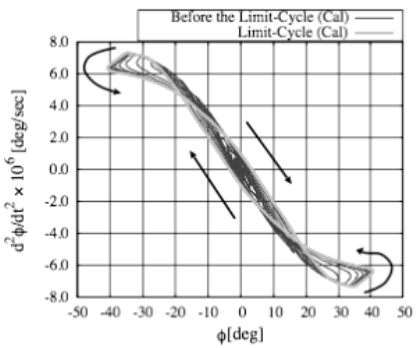

(b) $\phi-\ddot{\phi}$ 平面
第 7 図 相平面上のウイングロックの軌跡（摩擦なし）

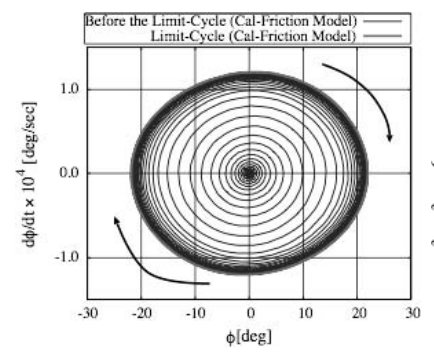

(a) $\phi-\dot{\phi}$ 平面

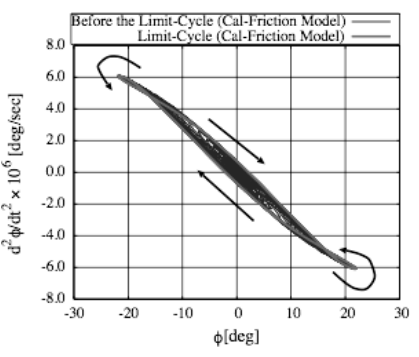

(b) $\phi-\ddot{\phi}$ 平面
第 8 図 相平面上のウィングロックの軌跡（摩擦あり）

変曲点を経た後，反対のピークへ向かう．同様の現象は過 去の研究1,2) でも確認されている。ただし，これらの報告 では上記の特徵がより明確で, 変曲点の後にいったん増加 して，2 度目の極值が見られた。対照的に，今回の実験結 果と摩擦を考慮した計算では，ロール角加速度の波形は大 きく変わることなく, ロール角変化が正弦関数により近い ものであることを示している.

これらの特徵を, $\phi$ を横軸, $\dot{\phi}, \ddot{\phi}$ を縦軸にした相平面 で示す，摩擦なしの結果を第 7 図 (a), (b)に，摩擦ありの 計算結果を第 8 図 (a), (b) に示す。これらの図にはデル夕 翼がウィングロックを始めてからリミットサイクルに至る までの軌跡が描かれている。図中の矢印は回転方向を示す. 第 7 図 (a), 第 8 図 (a) では, 軌跡は交差することなく原 点から出発し, 滑らかにリミットサイクルに近づいている. 第 7 図 (b), 第 8 図 (b) より, ロール角と角加速度のヒス 


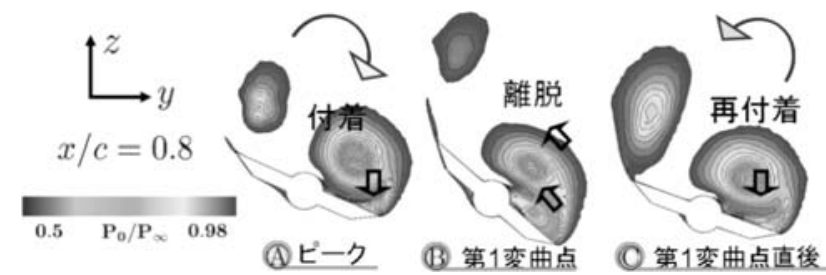

第 9 図 $x / c=0.8$ 断面における総圧分布（摩擦のない場合）

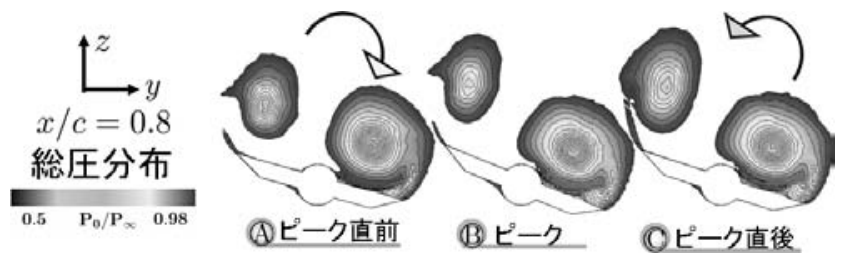

第 10 図 $x / c=0.8$ 断面における総圧分布（摩擦を考慮した場合）

テリシスが明確に見られる。文献1)，2)でも指摘されてい るように，一周期中に原点を挟む上下の曲線に囲まれる面 積分のエネルギを気流から受け，両端の閉じた曲線の面積 分のエネルギを気流に対して失う。

リミットサイクルでは 1 周期のエネルギ収支が 0 となる が，摩擦のない場合は気流とのエネルギの授受が，すべて 翼の運動エネルギの増減に費やされる。摩擦のある場合は, 両端の閉じた部分の領域が狭くなっており，この部分の面 積分のエネルギがスティングに働く摩擦エネルギとして消 費されたことを意味する。

次に，第 6 図のロール角加速度のピーク位置付近の流れ 場を調へ，角加速度の履歴の定性的な違いを考察する。第 6 図中，摩擦なしの結果の A，B，Cに拈ける， $x / c=0.8$ 断面の総圧分布を第 9 図に示す。A に打ける流れ場より, 右翼側で翼と前縁剝離渦の距離が小さく, 渦の負圧による 大きなモーメントが加わるために第 6 図に拉いて角加速度 のピークをとる. B ではロール角の増加により前縁剝離渦 が翼中央へ移行し，更に A では前縁付近にあった二次剥離 渦も大きく移行している.このため後方から見て反時計回 りのモーメントが一時的に小さくなり, 第 6 図中 A から B へと急減する。しかし C では翼の運動方向が反転し，再び 翼と前縁剝離渦との距離が小さくなるため，モーメントの 減少が緩やかになる。

一方，ベアリング摩擦を考慮した場合の同様の位置にお ける総圧分布を第 10 図に示す。これらの図より，3つの瞬 間に扔ける流机場に大きな差異は見られない。摩擦なしの 結果よりもロール角振幅が小さくなることによって, 剝離 渦が翼幅中央のスティングまで移動せず，その結果ロール 角加速度の変化も緩やかになったことが分かる。ロール角 最大付近では角速度がほほ 0 であるため, 摩擦モーメント は小さいため, 角加速度履歴の定性的な差が流体の挙動の 違いによるものと考えることは妥当である。また摩擦なし の結果に扔いて, 文献 1)，2) のように変曲点後の第 2 ピー クにまで至らない点についても，翼中央部のスティングが 逆方向への剝離渦の移動を抑えるためと考えられる。

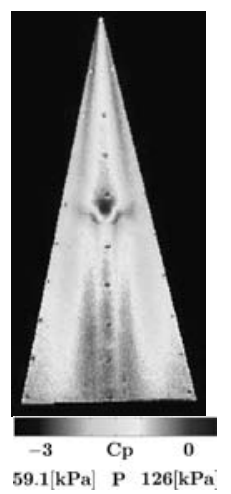

(a) PSP

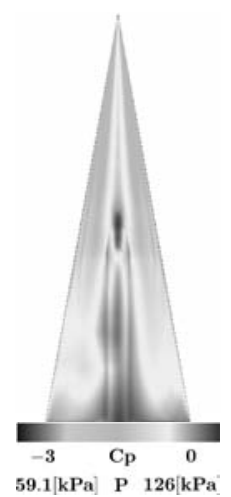

(b) CFD

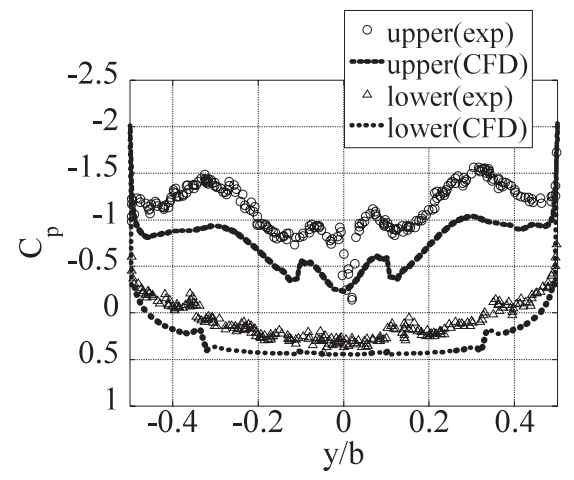

(c) $x / c=0.8$ における $C_{\mathrm{p}}$ 分布の比較

第 11 図 ロール角固定の翼面上圧力分布 $(M=0.5, \alpha=35 \mathrm{deg})$

4.2 翼面圧力分布の PSP 計測結果との比較 本節で は CFD による翼面圧力分布と実験で PSP によって得ら れた結果を比較して考察する。はじめにロール角 $0^{\circ}$ 固定 時（マッ八数 0.5 , 迎角 $35^{\circ}$ ) の翼面上圧力分布を示す. 第 11 図 (a) に実験結果を，(b)にCFD の結果を示す。圧力 上下限値はともに $59.1[\mathrm{kPa}]$ から $126[\mathrm{kPa}]$ に設定してい る。また第 11 図 (c) は $x / c=0.8$ に扔ける翼幅方向の圧力 係数 $\left(C_{\mathrm{p}}\right)$ 分布である.これらの図より, 翼上面の前縁剝 離渦の下の負圧ピーク，及び翼幅中央部のスティングによ る圧力の変動など, 定性的には良好に一致している。しか し定量性は十分とは言えず， $C_{\mathrm{p}}$ にして $0.3 \sim 0.5$ 程度，計 算結果が低圧になっている. 第 11 図に示す 2007 年の PSP 計測に先立つ 2006 年の実験では，その差は更に大きなも のであったが，PSP 計測において大面積 LED を用いるこ とによる照射強度と照射面積の増大，更に無風時と通風時 の LED 発光法の統一などの工夫により正確な圧力計測が 可能となった。これら計測方法の詳細については, 文献 6) を参照されたい。

CFD の精度の検証も行った. 前縁後退角 $76^{\circ}$, 前縁シャー プエッジのデルタ翼の, 静圧孔を用いた実験結果8) との比 較考察を行った。迎角は $20.5^{\circ}$, レイノルズ数は $0.9 \times 10^{6}$ であるが, 左右の半翼幅位置のトリッピングワイヤによる 乱流化が図られている. CFD は半裁のみの計算で，計算

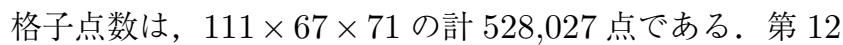
図に，無次元翼弦位置 $0.3 ， 0.5 ， 0.7 ， 0.9$ に打ける $C_{\mathrm{p}}$ 分 布の結果を示す. 翼前方部, $x / c=0.3,0.5$ に扔いては負 


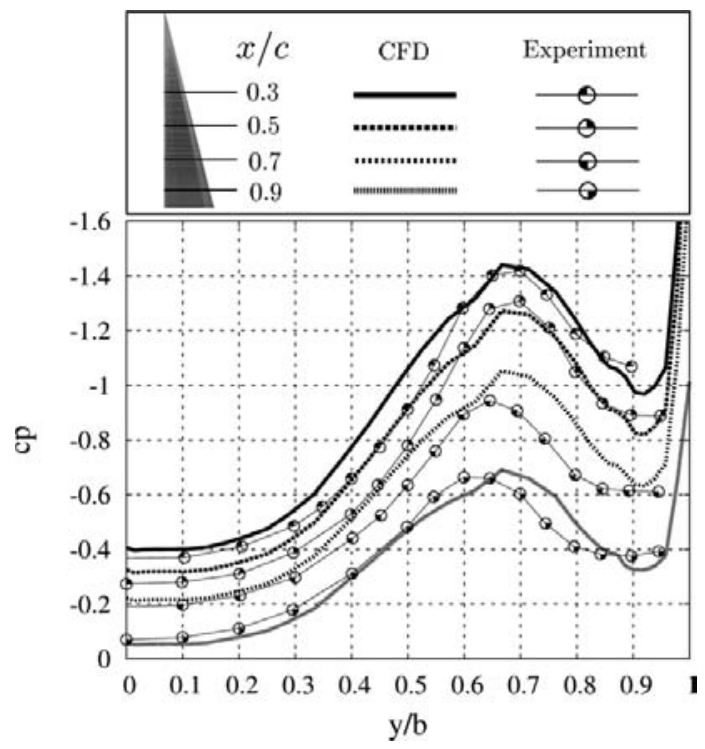

第12図 Hummel のデルタ翼による検証

圧のピーク值，翼幅中央部 $(y / b=0)$ の值とも一致は良 好である。一方，ピーク位置から中央部へ向かう変化の様 子，及び翼弦後方部では負圧ピーク位置の不一致が見られ る.これらは渦の乱れと前方との相対的な格子解像度の不 足に起因すると考えられるが, 圧力係数の上下限の予測は おおよそ適正であると言える。

第 11 図では実験, CFD ともに左右の非対称性が見られ る。さまざまな後退角を持つ, 静止したデル夕翼の前縁剝 離渦の安定限界を調べたWentz ら 9) や Polhamus ${ }^{10)} ら の$ 研究より, 第 11 図の条件（後退角 $80^{\circ}$, 迎角 $35^{\circ}$ ) では, 左右の渦の対称安定限界を超えて, 渦崩壊を起こすとされ ている.第 13 図 (a) の実験のシュリーレン写真では後縁付 近に急激な渦の変化が見られ，また，第 13 図 (b), (c)の $\mathrm{CFD}$ による流線と翼面上の逆流領域からも,$x / c=0.8$ 付 近で流線が大きく歪んでおり, この気流条件で渦崩壊を起 こす様子が分かる。この左右圧力差がローリングモーメン 卜を発生させ，ウィングロックを引き起こす．

4.3 ウィングロック時における翼面上圧力分布の比較 本節ではリミットサイクル時のウィングロックの翼面圧力 分布を調べる. $x / c=0.8$ 断面に扔ける $C_{\mathrm{p}}$ 分布と同断面の 流机の総圧分布を第 14 図に示す。ロール固定時と同様，翼 幅方向の負圧ピーク位置やスティングの影響など，翼面上 圧力の変化量は CFD と PSP で良好に一致している。 ロー 儿固定時と同程度の差が見られるが， $C_{\mathrm{p}}$ の全体的なシフト は，ローリングモーメントの差にはつながらない， 4.1 節 で示したロール運動の時間履歴からも，ローリングモーメ ントの推定值が適切であることを示している.

第 14 図に，リミットサイクルの半周期中の 7 つの瞬間に おける, $80 \%$ 翼弦位置の $C_{\mathrm{p}}$ 分布と総圧等高線を示し, 翼 の運動について考察する.PSP 計測結果が得られている瞬 間については, 同じグラフ中で比較する. 第 14 図 (a)〜 (d) ではロール角が減少し続け $(\dot{\phi}<0$, 翼後方から見て時計回 り), (e) でロール角の絶対值が最大に達し $(\dot{\phi}=0),(f)$,

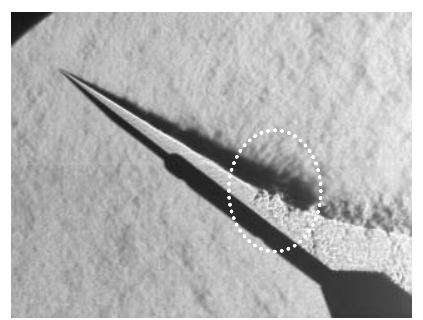

(a) シュリーレン写真 (実験5)

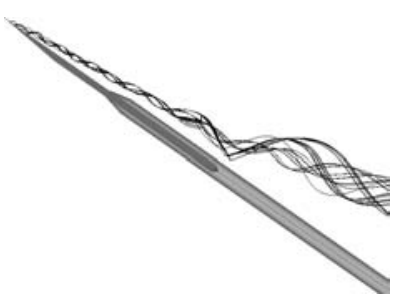

(b) 流線 (CFD)

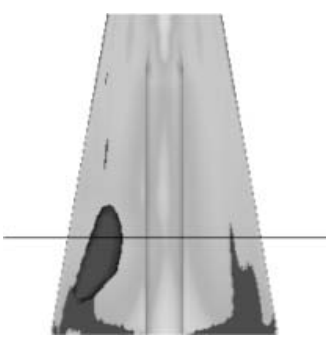

(c) 逆流領域 (CFD)
第 13 図 前縁剝離渦の不安定性 $(M=0.5, \alpha=35 \mathrm{deg})$

(g) では反転する $(\dot{\phi}>0$, 翼後方から見て反時計回り).ま た，第 14 図 (h) は, CFD による (d) (f) の瞬間の $C_{\mathrm{p}}$ 分 布の比較である。

まず (a)では，左翼が上昇し，右翼は下降している，左 翼上面の渦が翼に押し付けられるために渦中心下の翼面圧 力が低下し，逆に右翼は上面の渦から遠ざかるために相対 的に圧力が高く, その $C_{\mathrm{p}}$ 分布が平坦となり, 時計回りの モーメントが発生する。次に (b) では, ロール角は 0 である にもかかわらず，流れは明確な非対称性を示している。ま た，渦中心の総圧の低い領域は左右同程度となるものの， 運動の履歷から左翼と渦の距離の方が近いために, 未だ左 翼の揚力が高い. (c) の瞬間では, 左右の渦の強さは逆転 しており，また翼面と渦中心の距離も同程度となる。よっ て, $C_{\mathrm{p}}$ 分布からも，負のロール角を元に戻すような（反時 計回りの) 復元モーメントが発生すると分かる. (d), (e) とロール角が増すにつれて, 左右の渦の強さの差が大きく なり，(e)では，図中で最大のローリングモーメントが発生 する．また文献 2) でも指摘した通り, 翼上面の負圧だけで なく，下面の圧力も左右の揚力差を大きくし，ローリング モーメントを増大させる。 その後回転方向が逆転し，(f)， (g) では左翼が下降, 右翼が上昇する。ローリングモーメ ントは，この運動を助長するように作用する。(g)の総圧 分布, $C_{\mathrm{p}}$ 分布とも, $y=0$ に関して (a)の状態と左右対称 になっている. (a)の $y / b=-0.28,(\mathrm{~g})$ の $y / b=0.28$ 付 近の負圧ピークが，CFD では実験ほど顕著でないものの， 他の場所・時刻では, 渦の運動による圧力変化の傾向は良 好に一致していると言える.

第 14 図 (h) で，(e) 前後の (d) と (f) の $C_{\mathrm{p}}$ 分布を比較す ると, (f) で右翼の渦が翼面に圧されるために (d)よりも右 上面の圧力が低く，左翼では逆の現象が生じるため，空気 力によるローリングモーメントは (f) の方が大きい. しか しベアリング摩擦トルクは，(d) では空気力と同じ向きに 作用し, (f) では空気力と逆向きに作用する. 結果として, 

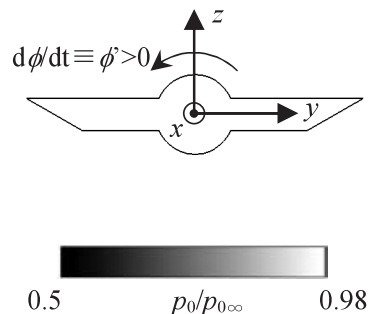

翼後方から見た軸とロール角速度の 定義 $(x / c=0.8$ 位置の翼断面 $)$
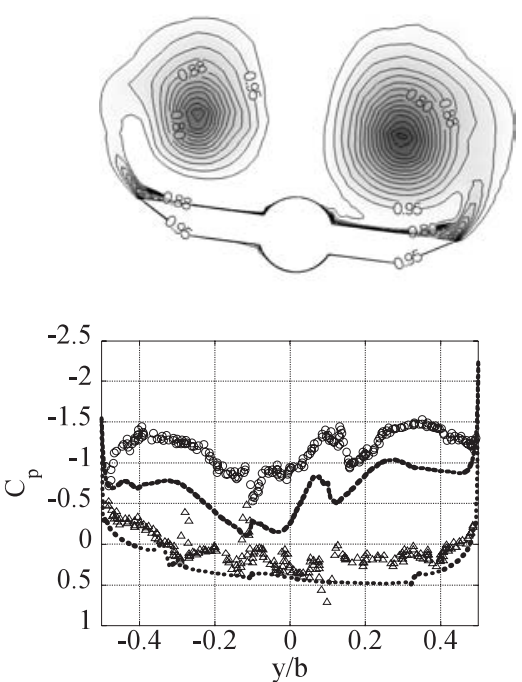

(c) $\phi=-8[\mathrm{deg}], \mathrm{d} \phi / \mathrm{d} t<0$
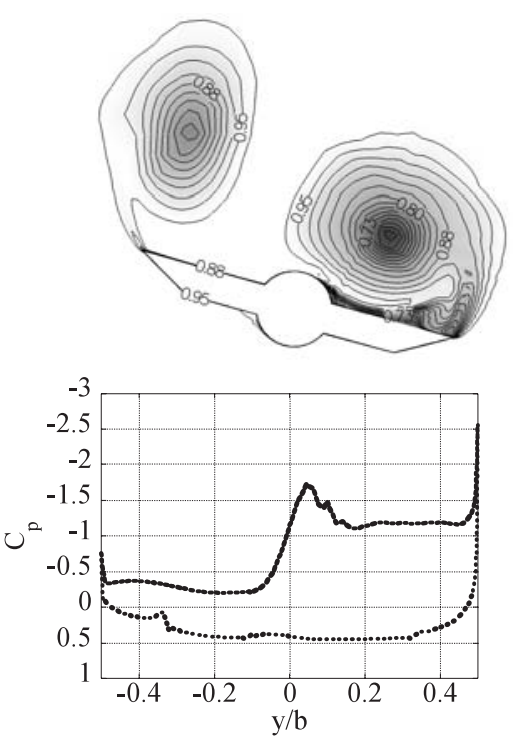

(f) $\phi=-15[\mathrm{deg}], \mathrm{d} \phi / \mathrm{d} t>0$
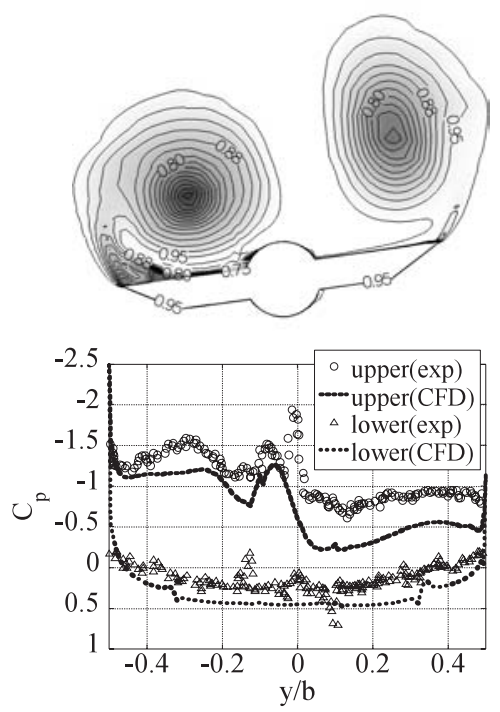

(a) $\phi=+8[\mathrm{deg}], \mathrm{d} \phi / \mathrm{d} t<0$
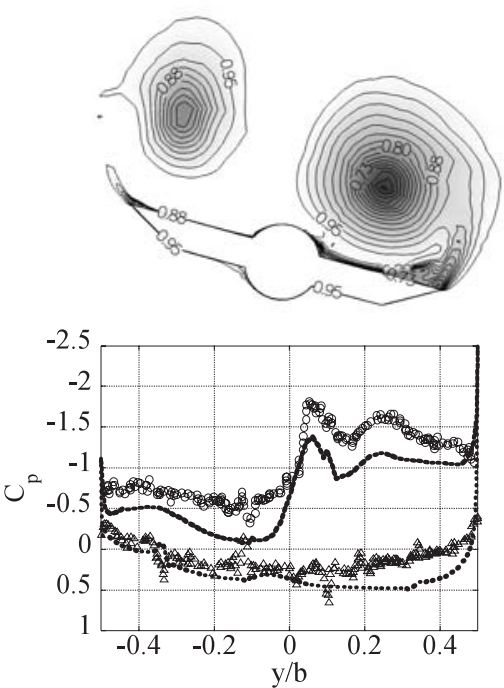

(d) $\phi=-15[\mathrm{deg}], \mathrm{d} \phi / \mathrm{d} t<0$
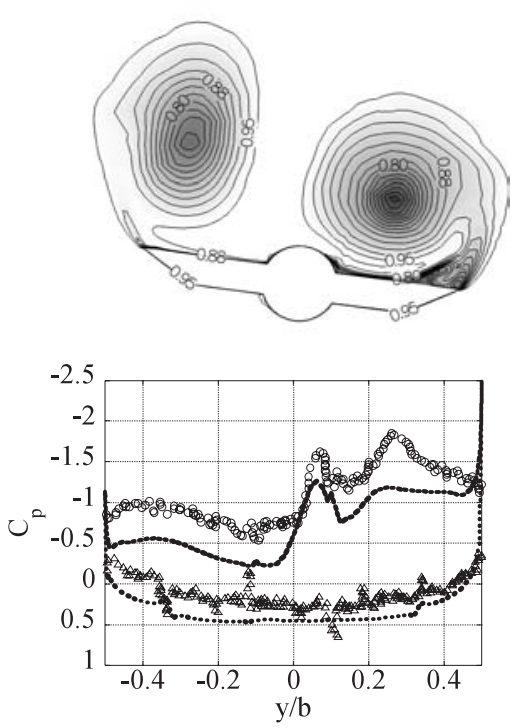

(g) $\phi=-8[\mathrm{deg}], \mathrm{d} \phi / \mathrm{d} t>0$
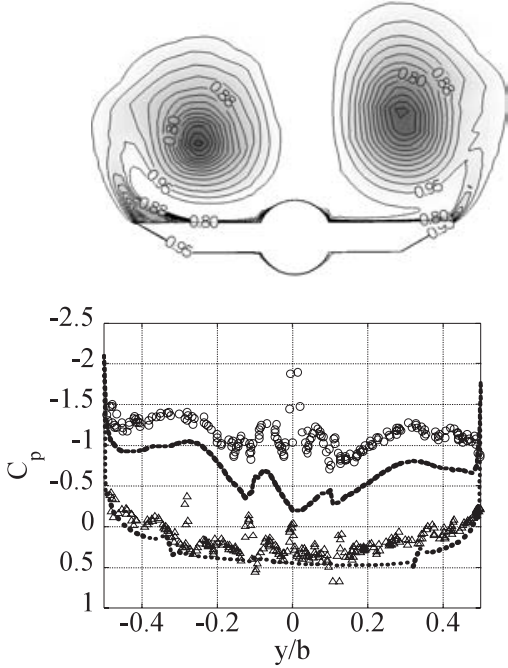

(b) $\phi=0[\mathrm{deg}], \mathrm{d} \phi / \mathrm{d} t<0$
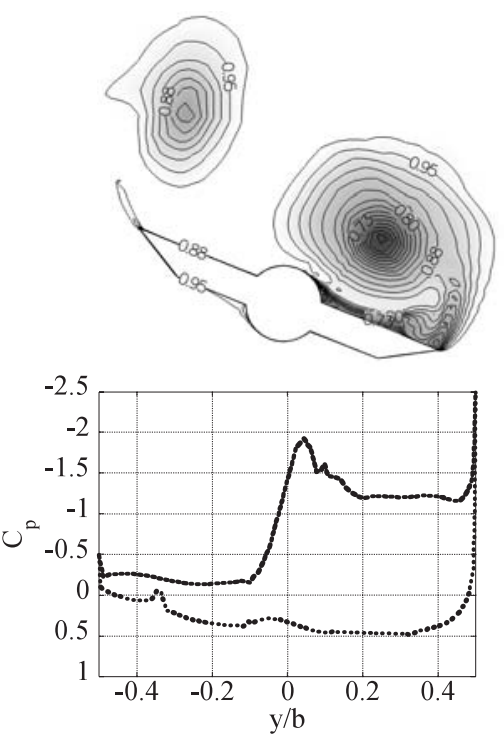

(e) $\phi_{\min }=-22[\mathrm{deg}], \mathrm{d} \phi / \mathrm{d} t=0$

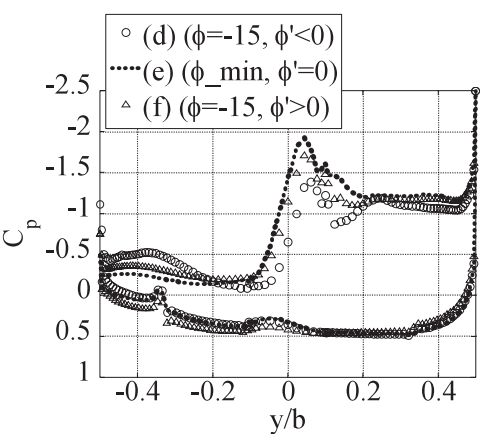

(h) $\phi_{\min }$ 付近の $C_{\mathrm{p}}$ 分布 $(\mathrm{CFD})$

第 14 図 $x / c=0.8$ 断面に扔ける総圧分布の流れ場と $C_{\mathrm{p}}$ 分布 


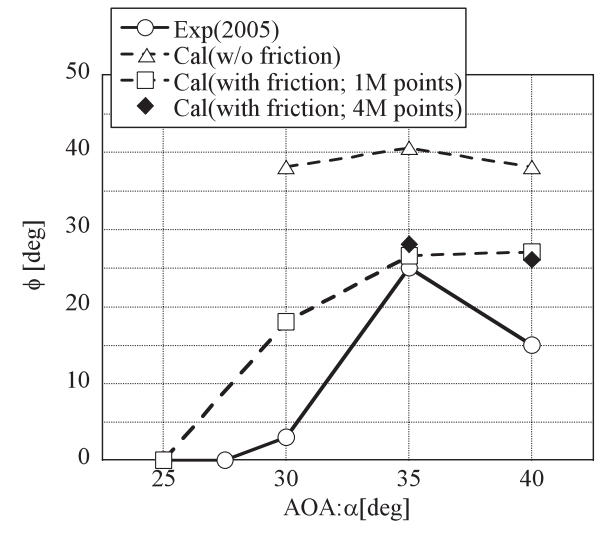

第 15 図 迎角を変化させた場合のロール角振幅

第 4 図と第 6 図に見られるように，ロール角最大值前後の 同一ロール角では，ほぼ同じロール角加速度となる。

4.4 ウィングロック発生領域の調査＼cjkstart前節までは, ロー ル角振幅が大きく, 最も明確な周期性を示すウイングロック 運動の考察を行った．本説では気流条件を変化させたときの ウィングロック発生の予測に関して調べた結果を示す。なお, 本節で参照するウィングロック発生領域の調査に関する実 験結果は, 2005 年の浅井らの研究5) に対応するものである.

マッハ数は $M=0.5$ 固定とし, 迎角を $25^{\circ}$ から $40^{\circ}$ ま で 5 刻みで変化させた。本計算においてもべアリング摩 擦の有無による翼運動への影響を調べた。迎角 $35^{\circ}$ と $40^{\circ}$ の 2 ケースについては, 計算格子点数を約 4 倍（約 400 万 点）とした計算も行った.

第 15 図に迎角を变化させた場合のロール角振幅を示す. まず，ここでもべアリング摩擦の考慮は必須であることが 分かる、摩擦なしではロール角振幅を過大に見積もってい るが，摩擦を考慮した場合は迎角に対し実験と同様の変化 の傾向を捉えている．以下では摩擦ありの計算結果につい て考察する. 迎角 $30^{\circ}$ 以上では実験, 数值計算ともにリミッ トサイクル振動になる。迎角が下がるにつれてロール角振 幅が減少し，25のときはロール動安定となるためにウィン グロックが発生せず，計算により動的な安定境界の予測が

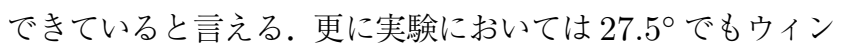
グロックは発生していないことから，25と $30^{\circ}$ の間にウィ ングロックの動安定性が変化する境界があることが分かる. 一方で, 迎角 $30^{\circ}$ と $40^{\circ}$ のリミットサイクル振動の振幅に 計算と実験で大きな差が見られる．前述のように，ウィン グロックは前縁剥離渦の不安定性から発生するが，これま での経験から格子解像度が不十分な場合は, 高迎角での前 縁剥離渦の崩壊を捉えられない傾向がある. そこで迎角 $35^{\circ}$ と $40^{\circ}$ の場合に格子点数を約 4 倍とした計算を行い, 格子 解像度の影響を調べた. 格子点数は, 翼弦長方向に 161 点, 円周方向は変化なし (191 点), 格子から離れる方向に 131 点の計 4,028,381 点である.

第 15 図中に示す結果より, 格子高解像度化によって $40^{\circ}$ におけるロール角の振幅に減少傾向は見られるものの, 有 意な差は得られていない。実験との定量的な比較という観
点からは, CFD 解析の更なる精度向上とともに, 摩擦モ デルの改良の可能性も考えられる. 特に, 迎角やマッハ数 が上がることで翼の受ける空気力が大きくなると, 摩擦係 数の变更や摩擦モデルの非線形性も考慮すべきと思われる. 自由飛行試験模擬のためには実験において, 摩擦を減じる 工夫をすることも必要である。

\section{5. 結論}

本研究では, マッハ数 0.5 , 迎角 $35^{\circ}$ の気流条件を中心と してウィングロックの数值シミュレーションを行い, その 予測精度を検証した. 著者らの過去の研究で開発した流体・ 翼運動の連成解析手法に，風洞実験固有のベアリングの摩 擦モデルを導入することで，翼の挙動が定量的に再現され た.これにより, 数值計算の信頼性の確認とともに, 風洞 実験と自由飛行試験の差異を示すことができた．また，ウィ ングロックに対する新たな解析手段として, PSP による非 定常圧力計測と CFD の比較を行った. 翼面上の圧力变化 の傾向は良好に一致しており, 総圧等高線で示された前縁 剝離渦の運動と関係づけて妥当な解釈がなされ, CFD は空 気力・モーメントだけでなく，局所的な流れも正しく捉え ていることが示された。定量的な差は埋めきれていないも のの, CFD と PSP の相互検証を通して, 本研究は計測手 法の精度の向上にも寄与することができた。

東北大学の浅井圭介教授, 永井大樹准教授には, 実験結 果の提供とともに, 結果の議論を通して有益な助言を得た. ここに謝意を表する。

\section{参 考 文 献}

1) 楯 篤志, 野田順一, 吉永 崇: デル夕翼ウィングロックと相平 面法による解析, 航空宇宙技術研究所報告, 1226 号, 1995.

2) 平野正隆, 宮路幸二：ロール軸周りに自由度を持つデルタ翼ウィ ングロックの数值シミュレーション, 日本航空宇宙学会論文集, 52 (2004), pp. 535-540.

3) Chaderjian, N. M.: Navier-Stokes Prediction of LargeAmplitude Delta-Wing Roll Oscillations, J. Aircraft, 31 (1994), pp. 1333-1340.

4) Chaderjian, N. M. and Lweis, B. S.: Numerical Simulation of Forced and Free-to-Roll Delta-Wing Motions, J. Aircraft, 33 (1996), pp. 93-99.

5) Hirose, Y. and Asai, K.: Unsteady Flow Measurements of a Slender Delta Wing in Wing Rock Motion, AIAA Paper 2007-124, 2007.

6) 杉本大輔, 西村洋介, 永井大樹, 浅井圭介：PSP を用いたデル 夕翼 Wing Rock 現象の非定常圧力計測, 平成 19 年度宇宙航行 の力学シシポジゥム, 2008.

7) Obayashi, S., Matsushima, K., Fujii, K. and Kuwahara, K.: Improvement in Efficiency and Reliability for Navier-Stokes Computations Using the LU-ADI Factorization Algorithms, AIAA Paper 86-338, 1986.

8) Hummel, D.: On the Vortex Formation over a Slender Wing at Large Angles of Incidence High Angle of Attack Aerodynamics, AGARD-CP-247, Paper No. 15, 1978.

9) Wentz, W. H. and Kohlman, D. L.: Vortex Breakdown on Slender Sharp-Edged Delta Wings, J. Aircraft, 8 (1971), pp. 156-161.

10) Polhamus, E. C.: Predictions of Vortex-Lift Characteristics by a Leading-Edge-Suction Analogy, J. Aircraft, 8 (1971), pp. 193-199. 